NordisK MuseOLOGI $2002 \cdot 2$, S. 38-4I

\title{
Tilbage til Færøerne
}

\author{
Arne Thorsteinsson
}

Ved en overdragelsesceremoni på Føroya Fornminnissavn den 26. juli 2002 blev henved et par hundrede museumsgenstande fra det danske Nationalmuseums samlinger overdraget Farøernes Nationalmuseum. Blandt disse genstande er det enestående middelalderlige kirkeinventar fra Farøernes bispesade i Kirkjubøur. Kirkeinventaret betragtes $i$ dag som Farøernes største nationale klenodie, og med overdragelsen opfyldtes et lange noret og mange gange fremsat farøsk ønske.

De færøske samlinger på Nationalmuseet er gennem tiderne indgået til Oldnordisk $\mathrm{Mu}-$ seum, Møntsamlingen, Dansk Folkemuseum samt Frilandsmuseet. Der har forunderlig nok ikke været nogen kulturhistoriske genstande fra Færøerne $i$ det kongelige Kunstkammer. De første museumsgenstande indgik til Oldnordisk Museum i 1820 på Oldsagskommissionens initiativ, og op gennem 1800 årene indsamledes der en række museumgenstande som resultat af kontakter mellem museet og embedsmænd og bønder på Færøerne, først og fremmest den afholdte og energiske landfoged og siden amtmand Plöyen, der som embedsmand opholdt sig på Færøerne fra 1830 til 1848. De til museet indsendte genstande bestod dels af kirkeinventar, som var gået ud af brug, og anden offentlig ejendom, så som danefæ og drivgods, og dels af genstande, som ved køb eller som gave erhvervedes til museet.

I 1898 oprettedes Færøernes Museum; derfter ebbede tilgangen til det tidligere Oldnordisk Museum, nu Nationalmuseet, ud.
Enkelte genstande fandt stadig vej dertil, den sidste i 1923.

I mellemtiden var der i Danmark blevet oprettet et nyt offentligt museum, Dansk Folkemuseum, som i 1920 blev indkorporeret i Nationalmuseet som dets 3. Afdeling nu Nyere Tids Samling. I slutningen af 1800 årene begyndte genstande fra Færøerne at tilgå Folkemuseet, og bl.a. i forbindelse med forberedelserne til Verdensudstillingen i Paris år 1900 foretog pioneren i udforskningen af norrøn kultur i Nordatlanten, Daniel Bruun, de første egentlige museale indsamlinger på Færøerne. De færøske samlinger på Folkemuseet og det tilknyttede Frilandsmuseum var dog ret beskedne frem til 1930erne, da den folkekære og energiske læge i Eidi på Eysturoy R.K.Rasmussen påbegyndte sine indsamlinger til Folkemuseet og i mindre omfang til Frilandsmuseet. Rasmussens samlinger er forbilledlige på grund af hans kræsne udvælgelse og omhyggelige dokumentation. Rasmussen og en række andre privatpersoner berigede Folkemuseets samlinger 


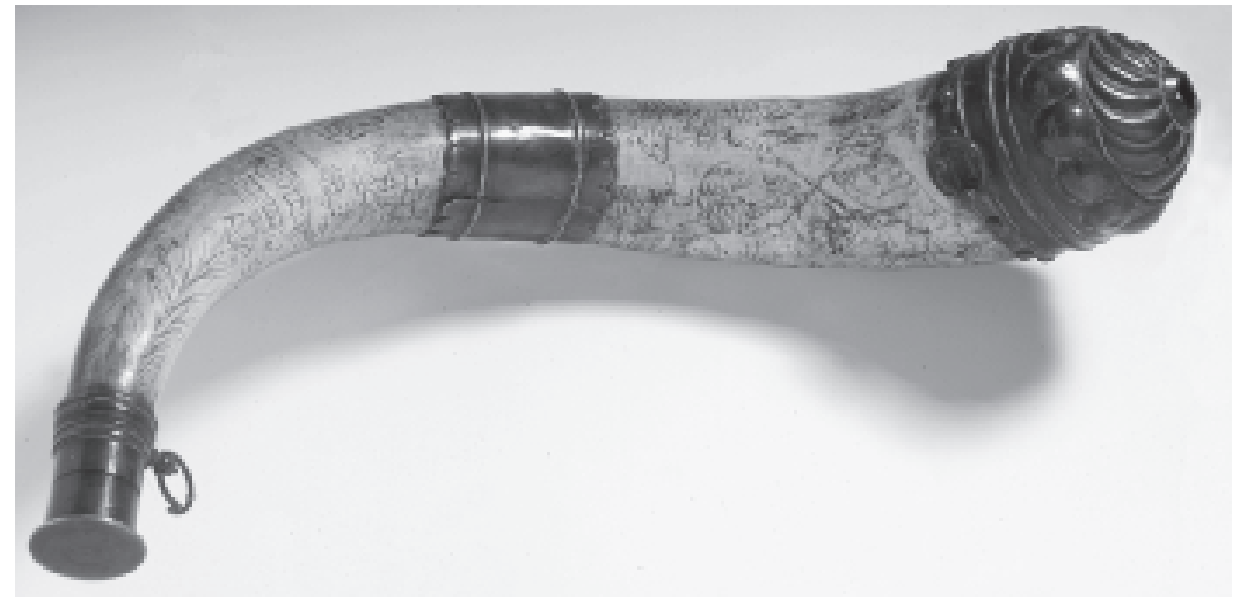

Herr Klements kruthorn. Praktstycke förvärvat 1646 av den legendariske prästen (1638-1681) på Sandoy, Clement Laugesen Follerup. Det är tillverkat av ett halvmeterlängt oxhorn och rikt dekorerat med jakt-och andra figurscener. Antas vara tillverkat $i$ någon europeisk verkstad.

frem til omkring 1960, hvorefter tilgangen direkte fra Færøerne afsluttedes med den mest omfattende og bedst organiserede indsamlingskampagne nogensinde, nemlig Bjarne Stoklunds indsamlinger for Frilandsmuseet til udstyr og møblering af den nyerhvervede færøske gård på Frilandsmuseet. Såvel gårdens erhvervelse som indsamlingskampagnen blev foretaget i god forståelse med Føroya Fornminnissavn og øvrige færøske myndigheder, som i forbindelse med hjemmestyrets indførelse i 1948 havde overtaget den antikvariske og museale lovgivning og administrationen deraf.

Tilbageføringsønskerne opstod allerede i begyndelsen af 1900 årene, da den kendte kirkjubøbonde og politiker Jóannes Patursson, mens han var rigsdagsmand, energisk arbejdede for at få det middelalderlige kirkeinventar tilbage til Kirkjubø. Hans og andres private bestræbelser bar dog ingen frugt. I
1955 tog det færøske lagting sagen op og fremsatte ønske om at få færøske samlinger i offentlig dansk eje overdraget til Føroya Fornminnissavn. I henvendelser til den danske regering i 1958 og 1976 nøjedes Færøernes landsstyre dog med at anmode om deponering på Føroya Fornminnissavn af kirkeinventaret fra Kirkjubø.

Den danske holdning til de færøske ønsker var fra 1961, da P.V.Glob blev rigsantikvar, overvejende positiv, og det var Globs fortjeneste, at man fra dansk side såvel i begyndelsen af 1960erne som i 1976-77 sørgede for at overdragelsessagen kom til at omfatte en deling af Nationalmuseets færøske samlinger som helhed. I 1977 gav først Nationalmuseet, siden Kulturministeriet og endelig den danske regering tilsagn om, at det middelalderlige kirkeinventar fra Færøernes bispesæde ville blive overdraget færøske myndigheder, så snart Føroya Fornminnissavn havde 
40 egnede lokaler til udstilling af museumsgenstandene. Ligeledes blev der givet tilsagn om, at andre museumsgenstande i Nationalmuseets samlinger samtidig ville kunne overdrages, således at den nærmere deling af samlingerne aftaltes mellem museerne.

Der skulle dog gå mange år, før Føroya Fornminnissavn så sig i stand til at opfylde de rimelige museale krav til at kunne påtage sig ansvaret for Færøernes største nationalklenodier. Lokalemæssige nyerhvervelser i 1980erne og 1990erne gav imidlertid stødet til, at overdragelsessagen blev genoptaget. I 1999 blev der indgået en samarbejdsaftale mellem Føroya Fornminnissavn og Nationalmuseet, hvorefter der blev nedsat et museumsfagligt samarbejdsudvalg med tre repræsentanter for hvert museum til gennemgang og fordeling af samlingerne. Udvalget afsluttede sit arbejde før jul 2001 med en indstilling til den danske kulturminister, som i marts måned 2002 underskrev overdragelsesdokumentet, hvorefter de til overførsel udvalgte genstande blev præsenteret for den danske offentlighed ved en afskedsudstilling på Nationalmuseet inden de i slutningen af juni måned 2002 blev sejlet til Færøerne.

Udvalgets arbejdede ud fra en omhyggelig vurdering af, hvor hver enkelt museumsgenstand måtte anses for at have størst værdi såvel i forskningsmæssig som i formidlingsmæssig henseende.

Dog besluttede udvalget så vidt muligt at påse, at sammenhørende genstandssamlinger forblev samlede på det ene af museerne.

Som hovedregel ville museumsgenstande af stor historisk betydning for Færøerne herefter blive overført til Føroya Fornminnissavn, herunder også genstande af lokalhistorisk og personalhistorisk betydning og ligeledes genstande, der var tjenlige til at udfylde huller i
Føroya Fornminnissavns samlinger eller dokumentere variationer i genstandsmaterialet.

Ligeledes som hovedregel så udvalget det som sin opgave at påse, at der - i betragtning af den århundredlange forbindelse mellem Færøerne og Danmark - fremdeles skal findes repræsentative færøske samlinger på $\mathrm{Na}$ tionalmuseet, og man var også enige om, at genstande, som Nationalmuseet anså for at have stor museumshistorisk interesse, skulle forblive på Nationalmuseet.

Endelig var man enige om under arbejdet med samlingernes deling at tage hensyn til særlige forhold, således at f.eks gaver som kronprins Frederik (VII) havde fået under sin rejse til Færøerne i 1844 og siden havde overladt museet, burde forblive, hvor de var, og ligeledes Frilandsmuseets færøske bygninger samt de genstande, som i forbindelse med deres erhvervelse var blevet indsamlet i god forståelse med de færøske myndigheder.

Enkelte af de overdragede genstande indgår i øjeblikket i Nationalmuseets udstillinger. De forbliver derfor på Nationalmuseet indtil videre, og museerne har derfor lavet en deponeringsaftale, som også omfatter nogle overdragne genstande, som det ikke endnu har været muligt at lokalisere i magasinerne.

Desuden er museerne er enige om, at afhændelse af disse for begge museer betydningsfulde samlinger, stiller krav om et tæt og tillidsfuldt samarbejde også i fremtiden. Der er derfor enighed om en aftale, hvorefter de to museers forskere også i fremtiden vil have fri og uhindret adgang til hinandens samlinger.

Arbejdet med at gennemgå Nationalmuseets færøske samlinger og drøftelserne omkring deres deling er foregået i en forbilledlig god atmosfære uden nogen gnidninger og hele tiden med hovedmålsæetngen for øje, nemlig at 
klargøre, hvor genstandene vil have størst værdi i forskningsmæssig og i formidlingsmæssig henseende. Naturligvis har der været diskussioner i samarbejdsudvalget, men aldrig uovervindelige hindringer for enighed.

Det har været en lykke for sagens gennemførelse, at den så snart det praktiske arbejde indledtes, har kunnet holdes på et fagligt, musealt plan. Der har ikke været noget stort politisk eller populistisk røre omkring sagen, hvilket har givet arbejdsro og har gjort, at man har kunnet opnå et resultat, som for Føroya Fornminnissavn er særdeles tilfredsstillende og som tjener Danmark og dets Nationalmuseum til ære.

\section{LITTERATUR}

Arne Thorsteinsson: "Úr útlegd". Føroya Fornminnissavn, søga og virksemi. Hoyvík 2002, 29-54.

Arne Thorsteinsson og Carsten U. Larsen: ”Tilbage til Færøerne. Deling af Nationalmuseets færøske samlinger". Nationalmussets Arbejdsmark 2002, 37-53 (Med yderligere henvisninger).

Arne Thorsteinsson

Fhv. Landsantikvar

Adr: FørøyaFornminnissavn, FO-110 Tórshavn

Fax: +298312259

E-mail:ArneThor@natmus.fo

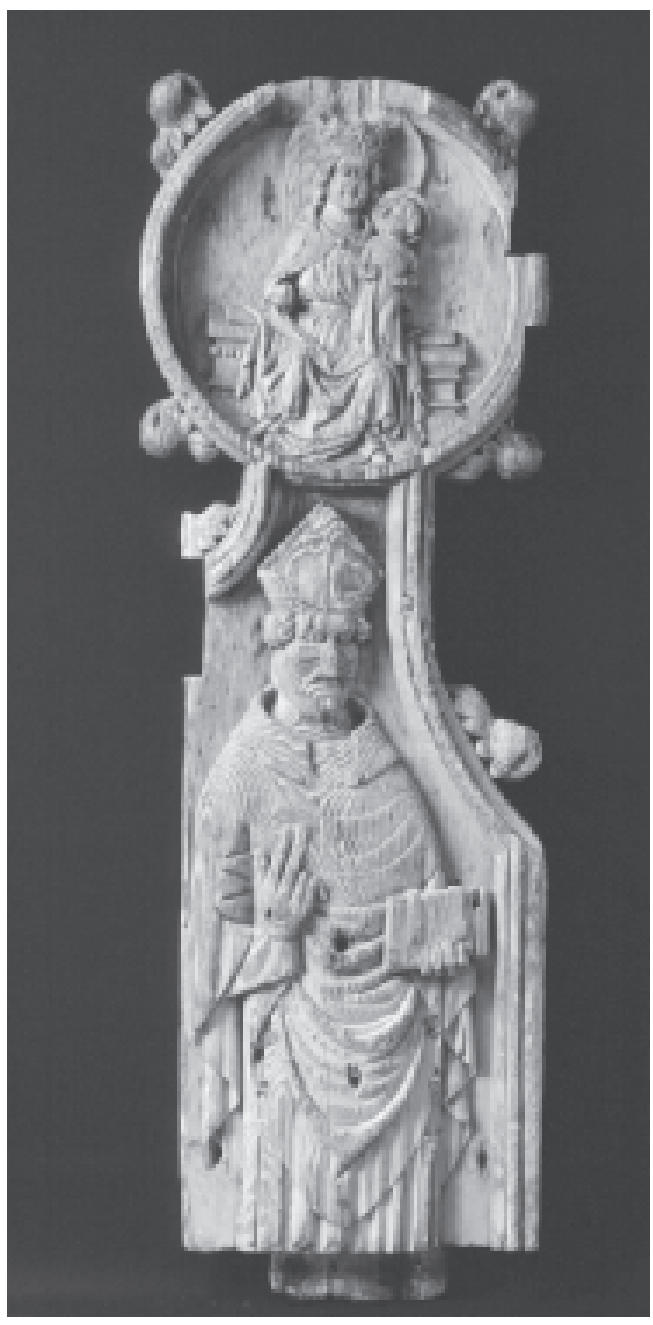

Sidostycke till läs-eller bönpulpet. Sidostyckena har senare suttit på en stol. Biskopen som avbildas antas föreställa den färöiske biskopen Erlendr (1269-1308). I det övre bildfältet Maria med barnet. Pulpeten skall ha tillkommit i perioden 1406-1430 för biskopssätet $i$ Kirkjubø på Färöarna. 